\title{
Nitrification Process in a Nuclear Wastewater with High Load of Nitrogen, Uranium and Organic Matter under ORP Controlled
}

\author{
Mariano Venturini ${ }^{1, *}$, Ariana Rossen ${ }^{2}$ and Patricia Silva Paulo ${ }^{1}$ \\ 1 Biomining and Environmental Biotechnology Laboratory-National Commission of Atomic Energy, \\ Av. Ptero González y Aragón N¹5, Buenos Aires B1802AYA, Argentina; silvapau@cae.cnea.gov.ar \\ 2 Microbiology Laboratory, Water Use Technology Center, National Water Institute, Au, Ezeiza Cañuelas, \\ Tramo J. Newbery km 1,6., Buenos Aires B1804, Argentina; arossen@ina.gob.ar \\ * Correspondence: mventurini@cnea.gob.ar; Tel.: +54-11-4125-8531
}

Citation: Venturini, M.; Rossen, A.; Paulo, P.S. Nitrification Process in a Nuclear Wastewater with High Load of Nitrogen, Uranium and Organic Matter under ORP Controlled. Water 2021, 13, 1607. https://doi.org/ $10.3390 /$ w13111607

Academic Editors: Shan Huang and Xi Chen

Received: 7 April 2021

Accepted: 24 May 2021

Published: 7 June 2021

Publisher's Note: MDPI stays neutral with regard to jurisdictional claims in published maps and institutional affiliations.

Copyright: (c) 2021 by the authors. Licensee MDPI, Basel, Switzerland. This article is an open access article distributed under the terms and conditions of the Creative Commons Attribution (CC BY) license (https:// creativecommons.org/licenses/by/ $4.0 /)$.

\begin{abstract}
To produce nuclear fuels, it is necessary to convert uranium's ore into $\mathrm{UO}_{2}$-ceramic grade, using several quantities of kerosene, methanol, nitric acid, ammonia, and, in low level, tributyl phosphate (TBP). Thus, the effluent generated by nuclear industries is one of the most toxic since it contains high concentrations of dangerous compounds. This paper explores biological parameters on real nuclear wastewater by the Monod model in an ORP controlled predicting the specific ammonia oxidation. Thermodynamic parameters were established using the Nernst equation to monitor Oxiders/Reductors relationship to obtain a correlation of these parameters to controlling and monitoring; that would allow technical operators to have better control of the nitrification process. The real nuclear effluent is formed by a mixture of two different lines of discharges, one composed of a high load of nitrogen, around 11,000 $\mathrm{mg} / \mathrm{L}\left(\mathrm{N}_{-} \mathrm{NH}_{4}{ }^{+}-\mathrm{N}_{-} \mathrm{NO}_{3}{ }^{-}\right)$and $600 \mathrm{mg} / \mathrm{L}$ Uranium, a second one, proceeds from uranium purification, containing TBP and COD that have to be removed. Bioprocesses were operated on real wastewater samples over 120 days under controlled ORP, as described by Nernst equations, which proved to be a robust tool to operate nitrification for larger periods with a very high load of nitrogen, uranium, and COD.
\end{abstract}

Keywords: thermodynamic parameters; nitrifying bacteria; bioprocess; nuclear effluent

\section{Introduction}

Nowadays, different societies around the world are claiming for more formal and robust legislation focused on environmental protection. Along with the development of the nuclear industry and its prospective applications on a large scale [1], there is an increased radioactive effluent that requires a stricter environmental normative. The International Atomic Energy Agency (IAEA) and Argentine legislation contemplate that effluent discharges from nuclear industries, considered as radioactive waste, should be zero; even though radioactive emissions remain at a harmless level [2].

Other industries such as explosives or exchange resin have effluents containing high levels of nitrogen that can be used as fertilizers [3,4]. However, effluents from the nuclear industry cannot further be used because they are considered hazardous for the environment and human health [5], and Argentinean legislations prohibit further uses of nuclear effluents [6].

If radioactive effluents are discharged directly into the environment, they will pollute water, atmosphere, and soil, threatening the environment and human health [7]. So, radioactive effluent treatments are becoming one of the most important issues that environmental legislation has to address [8].

To produce nuclear fuels, it is necessary to convert uranium's ore into $\mathrm{UO}_{2}$-ceramic grade, using several quantities of kerosene, methanol, nitric acid, ammonia, and, at a low level, tributylphosphate (TBP) [9]. Thus, the effluent generated by nuclear industries is one of the most toxic since it contains high concentrations of toxic compounds. 
In general, physicochemical treatments such as ammonia stripping, reverse osmosis [10,11], or Zero Liquid Discharge (ZLD) [12] are cost-effective methods employed for highly concentrated wastewater containing more than $1000 \mathrm{mg} \mathrm{N} / \mathrm{L}$ of the ammonium ion despite its high costs [13]. Other physicochemical strategies implemented are coupled to ionic exchange with reverse osmosis $[10,14,15]$ to obtain a better performance, though it requires recycled resin generating a secondary effluent. However, the cost-effectiveness of those physicochemical treatments increases dramatically.

By contrast, the biological nitrification and denitrification process seemed to be a promising technology to remediate nuclear effluent [16-18]. However, due to the high quality and quantity of nuclear effluents variability, biological treatments are difficult to implement with real samples [19]. Besides, microbial kinetic performance is lower than physicochemical ones, and even more, considering the complexity of interactions it is difficult to estimate the evolution of the microbiological process [20].

Wastewater nitrogen removal rates depend, in part, on the complete oxidation of ammonia [21]. Complete nitrification is carried out by two different microbial groups that can be studied separately as: the ammonia-oxidizing bacteria ( $\mathrm{AOB}$ ) that converts ammonia into nitrite, and then, the nitrite-oxidizing bacteria (NOB) that convert nitrite into nitrate, in a process called nitritation [22].

The last innovative technologies [23,24] are System for High-Activity Ammonium Removal Over Nitrite [SHARON), Anaerobic Ammonium Oxidation (ANAMMOX) [25,26], Complete autotrophic Nitrogen Removal Over Nitrite (CANON) $[27,28]$ and Simultaneous Nitrification-Denitrification (SND) [29]. Although this process is difficult to implement in an effluent with a high load of COD and uranium due to its toxicity levels. So, in general, tertiary treatment of waste is needed [30,31].

To monitor the switch "on and off" for each aeration period, oxidation-reduction potential (ORP) and $\mathrm{pH}$ are the key parameters to control the nitrification process [32]. Because ORP in the anoxic phase provides indication $[24,33]$ for total nitrogen removal efficiency and represents a quantitative indicator of the degree of completion of the mentioned chemical reaction $[34,35]$. So, ORP becomes a valuable parameter for real-time online control of nitrification and can be easily monitored using a peak signal on the controlling screen indicating the final of the nitrification process.

According to Chang [36], Nernst equations for online control of the biological process were based on a one-to-one stoichiometric relation for the oxidizing and the reducing species. In the present work, ORP changes in the treatment of nuclear wastewater effluent were investigated.

To do that, the nitrification process of a real wastewater sample was modeled and simulated studying ORP by thermodynamic equations to obtain parameters for optimum biological process in complex media at real conditions. The biological kinetics were studied by the Monod equation and the continuous DO parameters by online methodologies [37].

\section{Materials and Methods}

\subsection{Isolation Synthetic Medium}

Due to extreme physicochemical conditions of nuclear wastewater, no nitrification activity was detected in those effluents. Therefore, nitrifying biomass was isolated from a soil sample in a synthetic medium, and then acclimated to an organic load and real and nuclear wastewater.

The autotrophic medium was described by Kassen [38], per liter, $\mathrm{SO}_{4}\left(\mathrm{NH}_{4}\right)_{2} 1 \mathrm{~g}, 6 \mathrm{~g}$ of $\mathrm{CaCO}_{3}, 2 \mathrm{~g}$ of NaCl, $0.2 \mathrm{~g}$ of $\mathrm{MgSO}_{4} \cdot 7 \mathrm{H}_{2} \mathrm{O}, 0.5 \mathrm{~g}$ of $\mathrm{KH}_{2} \mathrm{PO}_{4}$, and $1 \mathrm{~mL}$ of traces elements $1 \mathrm{~g}$ Fe III-Citrate, $10 \mathrm{~g}$ of $\mathrm{MnCl}_{2} \cdot 4 \mathrm{H}_{2} \mathrm{O}, 10 \mathrm{~g}$ of $\mathrm{H}_{3} \mathrm{BO}_{3}, 5 \mathrm{~g} \mathrm{ZnCl}, 1 \mathrm{~g}$ of $\mathrm{Na}_{2} \mathrm{MoO}_{4} \cdot 2 \mathrm{H}_{2} \mathrm{O}$, $4 \mathrm{~g}$ of LiCl, $2.5 \mathrm{~g}$ of $\mathrm{KBr}, 2.5 \mathrm{~g}$ of KI, $5 \mathrm{~g}$ of $\mathrm{CoCl}_{2}, 0.5 \mathrm{~g} \mathrm{SnCl}_{2} \cdot \mathrm{H}_{2} \mathrm{O}, 1 \mathrm{~g}$ of $\mathrm{AlCl}_{3}, 20 \mathrm{~g}$ of EDTA, and $0.05 \mathrm{~g}$ of $\mathrm{CuSO}_{4}$. The inoculum was initialized at $5 \% v / v$ at $25^{\circ} \mathrm{C}, 120 \mathrm{rpm}$ in a $500 \mathrm{~mL}$ Erlenmeyer flask with a final volume of $250 \mathrm{~mL}$. Isolation of nitrifying bacteria 
were enriched and fed using ammonia as the energy source and carbonate as a carbon source in function of $\mathrm{pH}$ and the following parameters equation

$$
\mathrm{H}_{2} \mathrm{O}+\mathrm{CO}_{2} \Leftrightarrow \mathrm{H}^{+}+\mathrm{HCO}_{3}^{-} \Leftrightarrow \mathrm{H}_{2} \mathrm{CO}_{3} \text { with } \mathrm{K}=\left[\mathrm{H}^{+}\right] \cdot\left[\mathrm{HCO}_{3}^{-}\right] /\left[\mathrm{H}_{2} \mathrm{CO}_{3}\right] .
$$

\subsection{Blended Real Nuclear Wastewater (BRNW)}

Fuels from the nuclear power plant are obtained by uranium ore's processing which begins with the leaching of uranium ores converted into a "yellow cake" $\left(\mathrm{U}_{3} \mathrm{O}_{8}\right)$ that produces uranyl nitrate solution $(200 \mathrm{~g} \mathrm{U} / \mathrm{L})$ by dissolution in nitric acid $[39,40]$. These solutions carry out the precipitation of uranium oxide with anhydrous ammonia to produce ammonium diuranate (ADU).

Real nuclear wastewater samples consisted of mixing effluent streams from the argentine uranium conversion facility. This Blended Effluent from Real Nuclear Wastewater, named as BRNW hereafter, was composed of a mix of different discharge flows, to neutralize and dilute nitrogen concentration [41].

The first (1) stream was the current processing characterized by a $\mathrm{pH}=1$ and a concentration of nitrogen that varies between $11,000-14,000 \mathrm{mg} / \mathrm{L}\left(3 \mathrm{~N}-\mathrm{NH}_{4}{ }^{+} / 1 \mathrm{~N}^{-\mathrm{NO}_{3}}{ }^{-}\right)$. The second (2) stream came from a domestic industrial washing equipment effluent with a $\mathrm{pH}=9$ and $2700 \mathrm{mg} / \mathrm{L}$ total organic nitrogen and 13,000 $\mathrm{mg} / \mathrm{L}$ of COD with small quantities of TBP and detergent. Both effluents were mixed in such a relationship as to ensure that the final parameters were: $\mathrm{COD} 1500 \mathrm{mg} \mathrm{O}_{2} / \mathrm{L}, \mathrm{N}^{-\mathrm{NO}_{3}}{ }^{-}{ }^{-1000}-1400 \mathrm{mg} / \mathrm{L}$, and $\mathrm{N}-\mathrm{NH}_{4}{ }^{+} 600-1400 \mathrm{mg} / \mathrm{L}$ (around 1/10). The selected values of the parameters were obtained from the Monod maximum velocity (Vmax) and ORP determination, with the final $\mathrm{pH}$ adjusted to $\mathrm{pH}=7$.

Table 1 reveals that there have been three different periods to make acclimation. Strategies were carried out in three stages for 40 days. Stage 1, a synthetic media without nitrogen source, received a volume from stream 1 sample up to obtain a 500-700 mg/L ammonium concentration in the media. Stage 2 , was a synthetic medium with a sample of stream 2, incorporating COD to produce heterotrophic acclimatation. The final step consisted of an adaptation of the culture to BRNW reaching a $\mathrm{pH}$, nitrogen content, and COD to optimal growth of nitrifying bacteria.

Table 1. Characteristics of the acclimatation media for bacterial adaptation.

\begin{tabular}{ccccc}
\hline & & $\begin{array}{c}\text { Acclimation-Autothropic } \\
\text { Medium-Nuclear Effluent (Stage 1) }\end{array}$ & $\begin{array}{c}\text { Acclimation-Heterothropic } \\
\text { Medium (Stage 2) }\end{array}$ & $\begin{array}{c}\text { Blended Real Nuclear } \\
\text { Wastewater (BRNW) }\end{array}$ \\
\cline { 2 - 5 } & Unit & $\begin{array}{c}\text { Concentration } \\
\text { Minimum-Maximum }\end{array}$ & $\begin{array}{c}\text { Concentration } \\
\text { Minimum-Maximum }\end{array}$ & $\begin{array}{c}\text { Concentration } \\
\text { Minimum-Maximum }\end{array}$ \\
\cline { 2 - 5 } & $\mathrm{mg} / \mathrm{L}$ & $500-700$ & $600-900$ & $600-1400$ \\
Ammonium & $\mathrm{mg} / \mathrm{L}$ & $0-400$ & $100-800$ & $1000-1300$ \\
Nitrate & $\mathrm{mg} / \mathrm{L}$ & $6.0-8.0$ & 9000 & 1500 \\
$\mathrm{COD}$ & $\mathrm{mg} / \mathrm{L}$ & $6.0-8.0$ & $7.0-7.8$ \\
$\mathrm{pH}$ & & 0 & 0 & $300-600$ \\
Uranium & $\mathrm{mg}$ & & & \\
\hline
\end{tabular}

\subsection{Test Analysis}

The system was monitored using chemical and physical analyses of the influent and effluent based on the procedures described by Standard Methods for the Examination of Water and Wastewater [42]. Analyzed parameters were: $\mathrm{pH}(4500-\mathrm{H} \mathrm{B})$; chemical Oxygen Demand (COD-5220 D); nitrite $\mathrm{N}^{-\mathrm{NO}_{2}}{ }^{-}$(4500 B-FIA); nitrate- $\mathrm{N}^{-\mathrm{NO}_{3}}{ }^{-}$(4500 A). An analysis of the $\mathrm{NH}_{4}{ }^{+}$concentration was conducted using spectrophotometric determination by phenate method at $640 \mathrm{~nm}\left(4500-\mathrm{NH}_{3} \mathrm{FB}\right), \mathrm{NO}_{2}{ }^{-}$(4500 B-FIA) was completed using diazotization methods and $220 \mathrm{~nm}$ and Nitrate by absorption at 220/270 nm (4500 A-FIA). 


\subsection{Monod Kinetics Model}

The specific nitrification rate is commonly expressed by the multiplication of individual terms complexing the Monod-type expressions [43]. The used model was carried out with $10 \%$ of inoculum at $25^{\circ} \mathrm{C}$ and $120 \mathrm{rpm}$, to maintain $\mathrm{pH}=8$, supplemented with insoluble $\mathrm{CaCO}_{3}$.

Based on the above considerations, the following expression for the growth rate of ammonium oxidation were determined by linearization of Lineweaver-Burk, where Vmax and the ammonia affinity constant $\left(\mathrm{K}_{\mathrm{NH} 4}\right)$ were obtained under controlled incubation conditions in the Erlenmeyer flask [44]. The maximum nitrification rate (Vmax) was obtained by measuring initial velocity consumption of $\mathrm{N}_{-} \mathrm{NH}_{4}{ }^{+} \mathrm{mg} / \mathrm{L}$ day in a batch reactor operated at $25 \pm 1{ }^{\circ} \mathrm{C}$. Non-limiting DO conditions $\left(\left[\mathrm{O}_{2}\right]>5 \mathrm{mg} / \mathrm{L}\right)$, initial concentration at 480 up to $2300 \mathrm{mg} / \mathrm{L}\left[\mathrm{N}-\mathrm{NH}_{4}{ }^{+}\right]$were used. The inhibition of $\mathrm{K}_{\mathrm{i}}$ and $\mathrm{HNO}_{2}$ concentration was adjusted by the Haldane model as described by Carrera Muyo [45].

$$
\mathrm{V}=\mathrm{V}_{\max }\left[\frac{\mathrm{S}_{\left(\mathrm{N}-\mathrm{NH}_{4}^{+}\right)}}{\left(\mathrm{K}_{\mathrm{s}}+\mathrm{S}\right) \cdot\left(1+\frac{\mathrm{HNO}_{2}}{\mathrm{~K}_{\mathrm{i}}}\right)}\right]
$$

where: $\mathrm{V}=$ nitrification rate $\left(\mathrm{N}-\mathrm{NH}_{4}{ }^{+} \mathrm{mg} / \mathrm{L} \cdot\right.$ day $), \mathrm{Vmax}=$ Maximum nitrification rate $(\mathrm{N}$ $\mathrm{NH}_{4}{ }^{+} \mathrm{mg} / \mathrm{L} \cdot$ day), $\mathrm{S}=$ Ammonium Substrate Concentration $(\mathrm{mg} / \mathrm{L}), \mathrm{Ks}=$ Half Saturation $(\mathrm{mg} / \mathrm{L}), \mathrm{HNO}_{2}=$ nitrous acid concentration $\left(\mathrm{N}^{-N_{2}}{ }^{+} \mathrm{mg} / \mathrm{L}\right), \mathrm{Ki}=$ Inhibition constant by $\mathrm{HNO}_{2}(\mathrm{mg} / \mathrm{L})$.

Linear respirometry was verified by using $\mathrm{Na}_{2} \mathrm{CO}_{3} 1 \mathrm{M}$ consumed accordingly with the nitrogen ammonia concentration. Respirometry assays were performed according to Weissman-Ciudad methodologies [46] [47]. During online determination, linearization was considered between the range of 4 and $6.5 \mathrm{mg} \mathrm{O}_{2} / 1$. The respirogram was carried out in Sartorius 51 bioreactors where DO and $\mathrm{pH}$ were controlled by Mettler Toledo Sensor. The equation used is as follow:

$$
\left(\mathrm{NH}_{4(\mathrm{i})}\right) / \mathrm{Ln} \frac{\mathrm{NH}_{4(\mathrm{I})}}{\mathrm{NH}_{4(\mathrm{f})}}=\left(\mathrm{R}_{\mathrm{AOB}} \cdot \mathrm{T}-\mathrm{K}_{\mathrm{s}}(\mathrm{AOB})\right) /\left(\mathrm{Ln}_{\frac{\mathrm{NH}_{4(\mathrm{I})}}{\mathrm{NH}_{4(\mathrm{f})}}}\right)
$$

where $\mathrm{NH}_{(48 \mathrm{i})}=$ Initial concentration of ammonium N-NH${ }_{4}{ }^{+} \mathrm{mg} / \mathrm{L}, \mathrm{NH}_{(48 \mathrm{f})}$ = final concentration of ammonium $\mathrm{N}-\mathrm{NH}_{4}{ }^{+} \mathrm{mg} / \mathrm{L}, \mathrm{R}_{\mathrm{AOB}}=\mathrm{AOB} \mathrm{DO}$ rate $\mathrm{mg} / \mathrm{L}$.hour $\mathrm{K}_{\mathrm{s}}(\mathrm{AOB})=$ Oxygen saturation constant and $\mathrm{T}=$ time (hour)

The Monod nitrification rate was:

$$
\mathrm{V}=4.55 \cdot \mathrm{V}_{\max } \cdot(7.2-\mathrm{pH}) \cdot \mathrm{e}^{\Theta(\mathrm{T}-\mathrm{Tr})} \cdot \frac{(\mathrm{DO})}{\mathrm{K}_{\mathrm{pO}_{2}}+\mathrm{DO}} \cdot\left(\frac{\left(\mathrm{N}-\mathrm{NH}_{4}^{+}\right)}{\left(\mathrm{K}_{\mathrm{NH}_{4}^{+}}+\mathrm{N}-\mathrm{NH}_{4}^{+}\right) \cdot\left(1+\left(\frac{\mathrm{HNO}_{2}}{\mathrm{~K}_{\mathrm{i}}}\right)\right.}\right)
$$

where $\mathrm{V}\left(\mathrm{N}-\mathrm{NH}_{4}{ }^{+} \mathrm{mg} / \mathrm{L} \cdot\right.$ day $)$ and $\mathrm{Vmax}\left(\mathrm{N}^{-\mathrm{NH}_{4}}{ }^{+} \mathrm{mg} / \mathrm{L} \cdot\right.$ day $)$ are Monod parameters, DO $=$ dissolved oxygen $(\mathrm{mg} / \mathrm{L}), \mathrm{HNO}_{2}=$ Nitrous acid concentration $(\mathrm{mg} / \mathrm{L}), \mathrm{T}=$ temp and $\mathrm{T}_{\mathrm{r}}=$ ref. temp. $\left({ }^{\circ} \mathrm{C}\right)$ and $\mathrm{K}_{1}=$ inhibition constant by $\mathrm{HNO}_{2}(\mathrm{mg} / \mathrm{L})$. Operational factor $4.55[\mathrm{Y}(\mathrm{x} / \mathrm{s})]$ was incorporated to obtain a better performance according to empirical data.

Inhibition was considered as "competitive inhibition" based on the Haldane model. The linearization was operated with a low concentration of $\mathrm{HNO}_{2}$. The method used in this work to determine nitrification inhibition was the Haldane model. According to Carrera Muyo [45] S>>>KS, consequently, the equation was as follows:

$$
\frac{1}{\mathrm{~V}}=\frac{1 \cdot \mathrm{HNO}_{2}}{\mathrm{~V}_{\max }}+\frac{1}{\mathrm{~V}_{\max }}
$$

$\mathrm{V}\left(\mathrm{N}-\mathrm{NH}_{4}{ }^{+} \mathrm{mg} / \mathrm{L} \cdot\right.$ day $)$ and $\mathrm{Vmax}\left(\mathrm{N}_{-} \mathrm{NH}_{4}{ }^{+} \mathrm{mg} / \mathrm{L} \cdot\right.$ day $)$ are Monod parameters, and $\mathrm{HNO}_{2}$ Nitrous acid concentration(mg/L).

The influence of temperature on biological activity is often modeled by an Arrhenius equation: $\mathrm{V}=\mathrm{V}_{\max } \cdot \mathrm{e}^{\mathrm{\theta}(\mathrm{T}-\mathrm{Tr})}$ where $\mathrm{V}_{\max }(\mathrm{T})$ is the maximum specific growth rate and $\mathrm{V}$ 
is the growth rate at the actual temperature $\mathrm{T}$-Tr is the reference temperature and $\theta$ is the Arrhenius constant.

The theoretical reaction shows that approximately $1 \mathrm{~mol}$ of alkalinity $\left(\right.$ as $\left.\mathrm{Na}_{2} \mathrm{CO}_{3}\right)$ is consumed for every mol of ammonium oxidized [48].

$$
\mathrm{FA}=\mathrm{TAN} \cdot\left(\frac{1}{10(\mathrm{pH}-\mathrm{pKa}+1)}\right) \rightarrow \mathrm{pKa}=0.09+\frac{2730}{\mathrm{~T}(\mathrm{~K})}
$$

where FA = Free Ammonia (mg/L), TAN = Total Ammonia Nitrogen $(\mathrm{mg} / \mathrm{L}), \mathrm{pKa}=$ Affinity constant $\left(\mathrm{NH}_{4}{ }^{+}\right)$and $\mathrm{T}=$ temperature $\left(\mathrm{K}^{\circ}\right)$

Proton production was proportional to oxidized ammonium, and to maintain $\mathrm{pH}$, equivalent volume $(\mathrm{ml})$ of carbonate solution were pumped into the bioreactor. Therefore, TAN could be estimated during online processes.

$$
\mathrm{TAN}=\mathrm{TAN}-\left(\frac{\mathrm{ml} \cdot \mathrm{Vs} 14 \mathrm{gl} \frac{\mathrm{N}}{\mathrm{mol}}}{\mathrm{Y}_{\frac{\mathrm{CO}_{3}^{2-}}{\mathrm{N}-\mathrm{NH}_{4}^{+}} \cdot \mathrm{TAN}}}\right)
$$

TAN = Total Ammonia Nitrogen $(\mathrm{mg} / \mathrm{L}), \mathrm{N}=$ nitrogen, $\mathrm{Y}_{\frac{\mathrm{CO}_{3}^{2-}}{\mathrm{N}^{-} \mathrm{NH}_{4}^{+}}}=$Carbonate/ammoniun yield, and $\mathrm{ml} \cdot \mathrm{Vs}=\mathrm{ml}$ Carbonate added.

To corroborate online ammonium oxidation, the consumption of $1 \mathrm{M}$ carbonate was utilized to monitor the process. These studies were evaluated using a "point-to-point" rate (Velf-Vel0)/(final time-initial time).

\subsection{Control of Environmental Conditions to Monitor ORP and in Relation to Monod Parameters}

The ORP and $\mathrm{pH}$ were determined by Mettler Toledo sensor $\mathrm{pH} 2100$. Ammonium concentration $\left({\mathrm{N}-\mathrm{NH}_{4}}^{+}\right)$, nitrite $\left({\mathrm{N}-\mathrm{NO}_{2}}^{-}\right)$, and nitrate $\left({\mathrm{N}-\mathrm{NO}_{3}}^{-}\right)$were carried out according to standard methods (See Section 2.3).

The ORP model was proposed by Chang-Cheng [36] based on the Nernst equation

$$
\mathrm{E}=\mathrm{E}^{\circ}+\frac{\mathrm{RT}}{\mathrm{nF}} \cdot \operatorname{Ln}\left[\mathrm{NH}_{4}^{+}\right]+\frac{2 \mathrm{RT}}{\mathrm{nF}} \cdot \operatorname{Ln}[\mathrm{DO}]+\frac{2 \mathrm{RT}}{\mathrm{nF}} \cdot \operatorname{Ln}\left[\frac{1}{\mathrm{NO}_{3}^{-}}\right]+\frac{2 \mathrm{RT}}{\mathrm{nF}} \cdot \operatorname{Ln}\left[\frac{1}{\mathrm{H}_{2} \mathrm{O}}\right]+\frac{2 \mathrm{RT}}{\mathrm{nF}} \cdot \operatorname{Ln}\left[\frac{1}{\mathrm{NO}_{2}^{-}}\right]+\frac{2 \mathrm{RT}}{\mathrm{nF}} \cdot \operatorname{Ln}\left[\frac{1}{\mathrm{H}}\right]
$$

$\mathrm{E}=\mathrm{ORP}$ value $(\mathrm{mV}), \mathrm{E}^{\circ}=$ Standard Potential $(\mathrm{mV}), \mathrm{RT} / \mathrm{nF}$ Nernst parameters, nitritation and nitratation: $\mathrm{DO}, \mathrm{NH}_{4}{ }^{+}, \mathrm{NO}_{2}{ }^{-}, \mathrm{NO}_{3}{ }^{-},(\mathrm{mg} / \mathrm{L})$ and $\mathrm{H}=$ proton reduction.

The standard potential $\left(\mathrm{E}^{\circ}\right)$ used in this work were ammonium oxidation to nitrite $\left(\mathrm{NO}_{2}{ }^{-}\right)=154 \mathrm{mV}$ and nitrate $\mathrm{E}^{0}\left(\mathrm{NO}_{3}{ }^{-}\right)=-340 \mathrm{mV}$. The original equation was modified by replacing $\ln (1 /[\mathrm{H}+])$ for $2.3026 \times x \times 4 \mathrm{pH}$ according to the author:

$$
\begin{gathered}
\mathrm{E}=\mathrm{E}^{\circ}+\frac{\mathrm{RT}}{\mathrm{NF}} \cdot \operatorname{Ln}\left[\frac{\left(\mathrm{NH}_{4}^{+}\right) \cdot(\mathrm{DO}) \cdot\left(\mathrm{H}_{2} \mathrm{O}\right)}{\left(\mathrm{NO}_{\mathrm{x}}^{-}\right) \cdot(\mathrm{H})^{(8 \text { or } 6)+}}\right] \\
\mathrm{E}_{0}\left(\mathrm{NO}_{2}{ }^{-}\right)=154 \mathrm{mV} \mathrm{E}{ }_{0}\left(\mathrm{NO}_{3}{ }^{-}\right)=-340 \mathrm{mV} \\
\mathrm{E}=-340 \mathrm{mV}+\left(\frac{0.059}{6} \cdot \log \mathrm{DO}\right)+\left\{61 \cdot \mathrm{pH}-59.88 \cdot \log \frac{\left[\mathrm{NH}_{4}^{+}\right]}{\left[\mathrm{NO}_{\mathrm{x}}^{-}\right]}\right\}
\end{gathered}
$$

Dissolved Oxygen (DO) concentration was considered constant due to agitation and forced air injection rate throughout the test and at an initial stage when biomass did not have a considerable consumption of oxygen. This value was $8 \mathrm{mg} / \mathrm{L}$ at $25^{\circ} \mathrm{C}$, according to the standardized table $\left(\mathrm{pO}_{2}\right)$. 


\subsection{Inhibition Assays: Maximum Load of Blended Real Wastewater}

To study the toxicity effect of the effluent, inhibition of Nitrifier bacteria was determined by ammonium oxidation rate. Using a pre-established culture in Erlenmeyer flasks, BRNW samples were added from $5 \%$ up to $50 \%(5,10,15,20$, and $50 \%)$ to the autotrophic medium.

To compare kinetic performance between biofilm vs. planktonic cells removal efficiency was evaluated using hydrogels as a carrier. Biomass was cultivated over 100 days with a semi-continuous process [49]. To do that, the Erlenmeyer flask was inoculated with $50 \mathrm{~mL}$ of nitrifying bacteria of approximately $5 \% v / v$ per liter with hydrogel carriers.

In the first lag period of the nitrifying process, no organic carbon sources were provided to reduce heterotrophic growth. After that stage, once the biofilm was formed onto hydrogel carriers, BRNW was added at an increasing concentration to adapt biomass.

\subsection{Pre Scale-Up Operations in Moving Bed Bioreactor (MBBR) using BRNW}

The biomass added onto carriers were cultivated in autotrophic media for 40 days in Sartorius Biostat APlus Bioreactor. After that, biomass was acclimated to BRNW for another 40 days. The ORP value was kept above $100 \mathrm{mV}$ to guarantee the nitrification process. To establish the best nitrifier performance and avoid nitrite accumulations, the bioassay was carried out under two different values of $\mathrm{pH}, 7.2$ and 7.8. Obtaining better results at 7.2 without nitrite accumulation. The oxygen was supplied with a constant flow of $2 \mathrm{lpm}$ of air and $200 \mathrm{rpm}$.

\subsection{Mathematical Models}

Linear and nonlinear regression analyses were used to fit the best baseline data for uptake. Nitrification rates with increasing $\mathrm{N}^{-\mathrm{NH}_{4}}{ }^{+}$concentrations were analyzed with nonlinear regression using Origin Microcal 8.0: computes, squares estimates were given by nonlinear Hill with $\mathrm{n}=1$. All linear regression were applied by default method.

\section{Results and Discussion}

\subsection{Monod Kinetic Parameters}

It is commonly assumed that nitrification bioprocess has zero or first-order kinetic, this assumption does not consider the role of biological factors and environmental influence over bacterial metabolism. Monod model is used to describe growth rate and inhibition growth factor, therefore, in this work, it is proposed a Monod model under a high load of nitrogen condition to describe a nitrification rate.

Figure 1A shows kinetic nitrification obtained by the Monod model (Hill->n = 1). The rose circle line represents the negative control (absence of microorganisms). At a higher concentration of ammonium, the lag phase takes longer times. Ammonium curves decline at different times over the incubation period: 7, 10, 12, and 13 days for 240, 490, 900, and, finally, $1380 \mathrm{mg} / \mathrm{L} \mathrm{N}-\mathrm{NH}_{4}{ }^{+}$respectively. It could be explained for the adaptation time to free ammonia concentration [50].

Even though, at a higher concentration, it requires a longer lag phase, the velocity of the reaction is increased as it is shown in Figure 1B as the first derivative. The velocity had an inversely trend at initial ammonium concentration showing a more abrupt decline slope, according to the Monod model in function of the initial substrate concentration. Therefore, for higher concentrations, the velocities of ammonium oxidation were higher as well, which represents an important parameter for the bioprocess of BNRW.

Figure 1C,D show the maximum velocities that fit the Monod equation and the results obtained by linearization (following the Lineweaver-Burk method), respectively. 

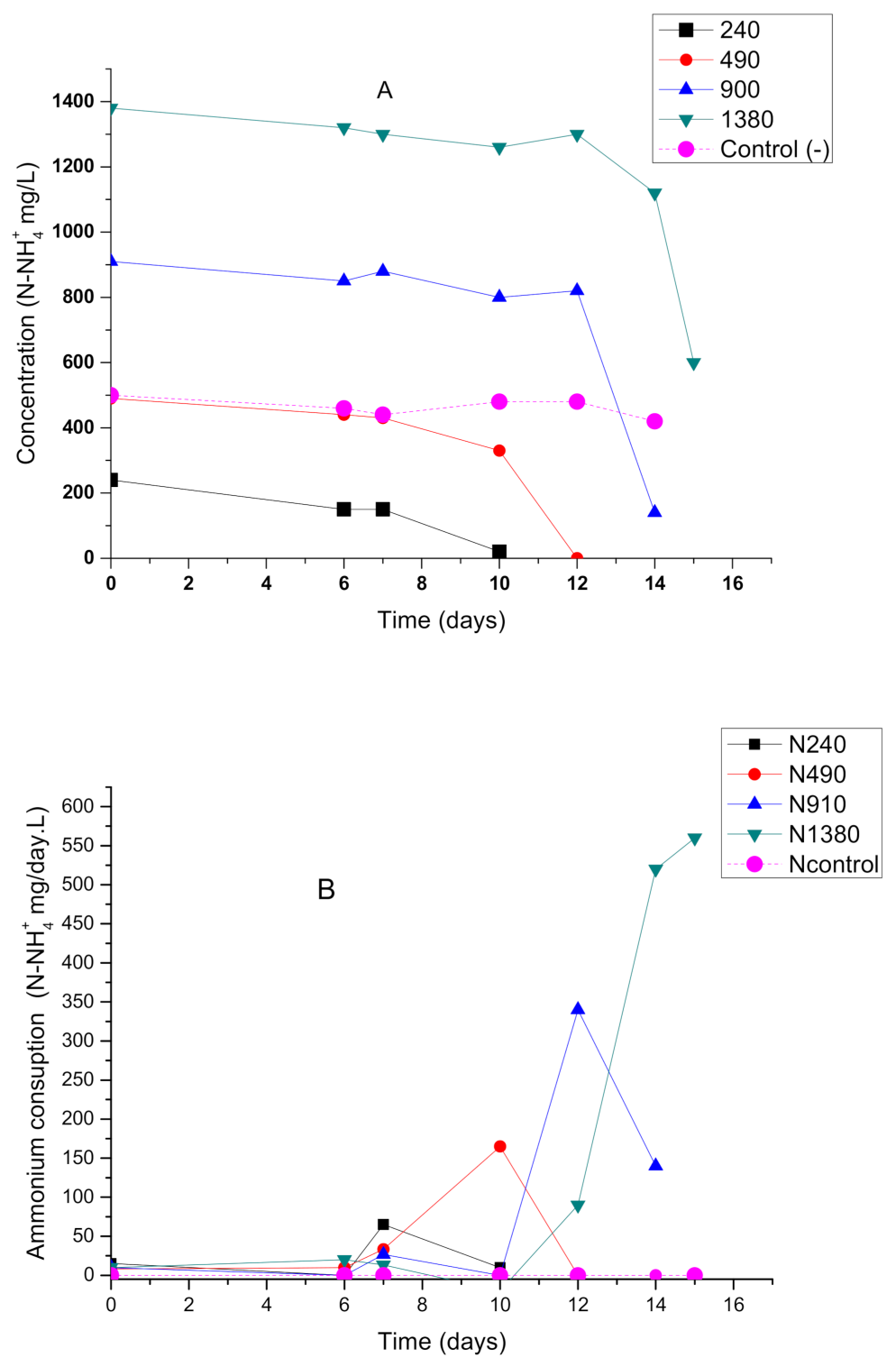

Figure 1. Cont. 

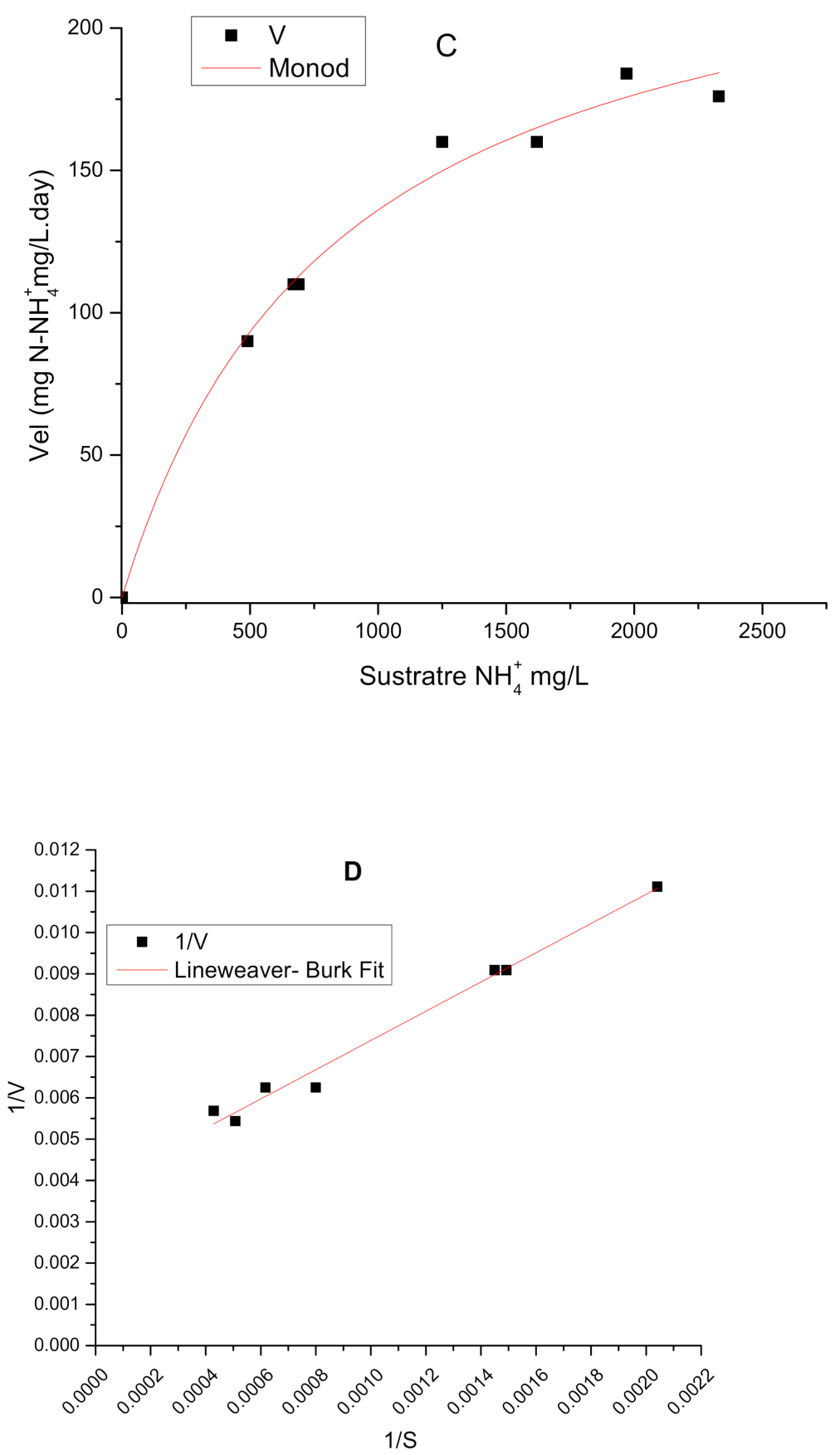

Figure 1. (A) Effect of initial ammonium concentration during lag phase. (B) Velocity evolution over time as a function of substrate addition. (C) Maximum velocity as a function of initial substrate and time (D) linearization.

Figure 2 shows that the maximum velocity was restricted to $1380 \mathrm{mg} / \mathrm{L}$ of ammonium, due to Ammonia/Ammonium equilibrium which also depends on $\mathrm{pH}$ and concentration (pKA). Free ammonia $\left(\mathrm{NH}_{3}\right)$ can easily penetrate the cells producing a competitive inhibition effect, affecting biological activity according to $\mathrm{pH}$ and $\mathrm{pKa}$ values.

As was demonstrated by Anthonisen [51], uncharged ammonia is a substrate for the ammonium oxidizer bacteria and can easily penetrate the membrane cell. In this work, it was also observed, an inhibition process by substrate and is related to $\mathrm{pH}$ by the following expression:

$$
\mathrm{S}_{\mathrm{NH}_{3}}=\left(\frac{\mathrm{NH}_{3}}{\mathrm{NH}_{4}^{+}}\right) /\left[1+\left(\frac{10^{-} \mathrm{pH}}{\mathrm{K}_{\mathrm{eq}} \cdot \mathrm{NH}_{4}^{+}}\right)\right]
$$


Being $\mathrm{S}_{\mathrm{NH}_{3}}=$ susbtrate ammonium, $\mathrm{NH}_{3}$ and $\mathrm{NH}_{4}{ }^{+}(\mathrm{mg} / \mathrm{L})$ and $\mathrm{K}_{\mathrm{eq}}=$ equilibrium constant.

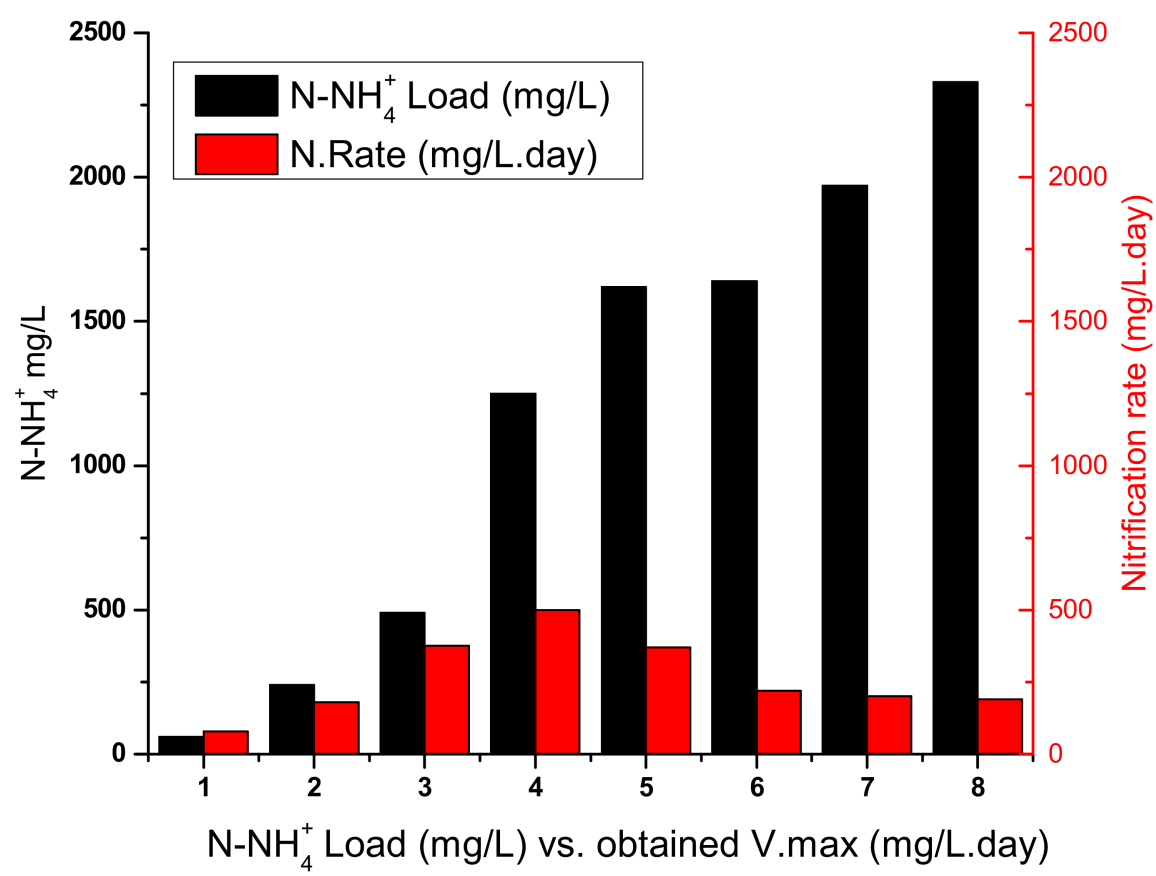

Figure 2. Maximum load of $\mathrm{N}_{-} \mathrm{NH}_{4}{ }^{+}$and nitrification performance.

This expression illustrates the relationship between ammonia/ammonium modified by $\mathrm{pH}$ and their concentrations and impacts the kinetics inhibition.

As it was mentioned before, the results of this study indicate that the maximum load of ammonium $\left(1380 \mathrm{mg} / \mathrm{L} \mathrm{N}-\mathrm{NH}_{4}{ }^{+}\right)$reaches the $\mathrm{Vmax}\left(251 \mathrm{~N}-\mathrm{NH}_{4}{ }^{+} \mathrm{mg} / \mathrm{L} \cdot\right.$ day $)$.

Figure 3 shows the linearization used to obtain the inhibition constant by nitrous acid $\left(\mathrm{HNO}_{2}\right)$ according to the Haldane model. Similarly to free ammonia, the uncharged $\mathrm{HNO}_{2}$ can penetrate the cells considering a pKa of 4.5. As with ammonia, low levels of nitrite should be maintained to avoid inhibition.

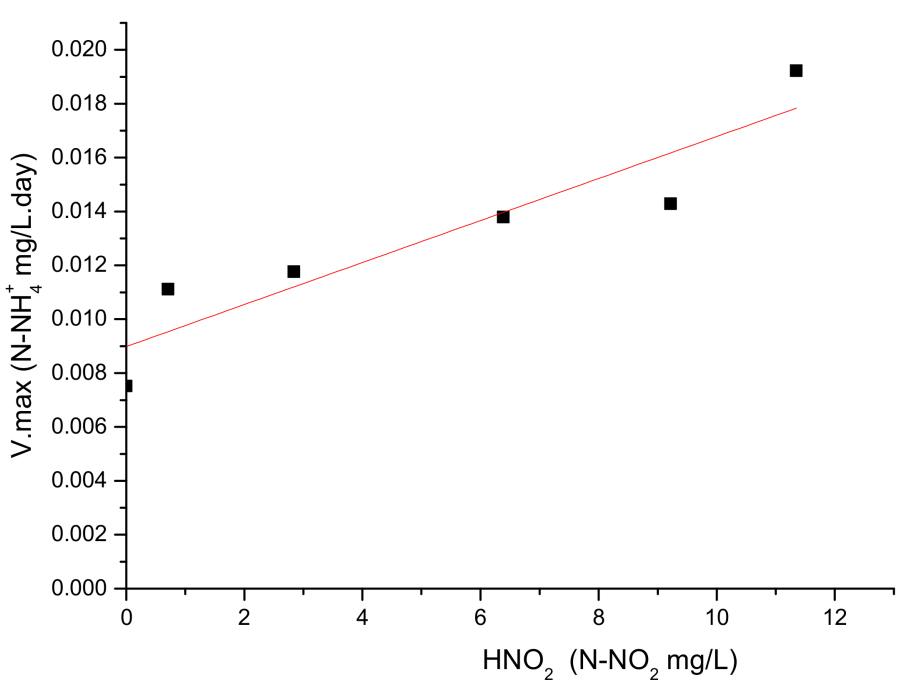

Figure 3. Competitive inhibition by $\mathrm{HNO}_{2}$.

Another crucial factor in this type of process is the dissolved oxygen level $[52,53]$. The oxidation reaction was ensured at a high level of DO supply to the medium to avoid having a limiting factor to autotrophic bacteria. Because of that, oxygen was strictly maintained 
between 4 to $6 \mathrm{mg} / \mathrm{L}$ (DO) to ensure not only limitations to autotrophic bacteria but also be adjusted to a linear fit according to Ciudad $[46,47]$. The results obtained by this methodologies are shown in Figure 4.

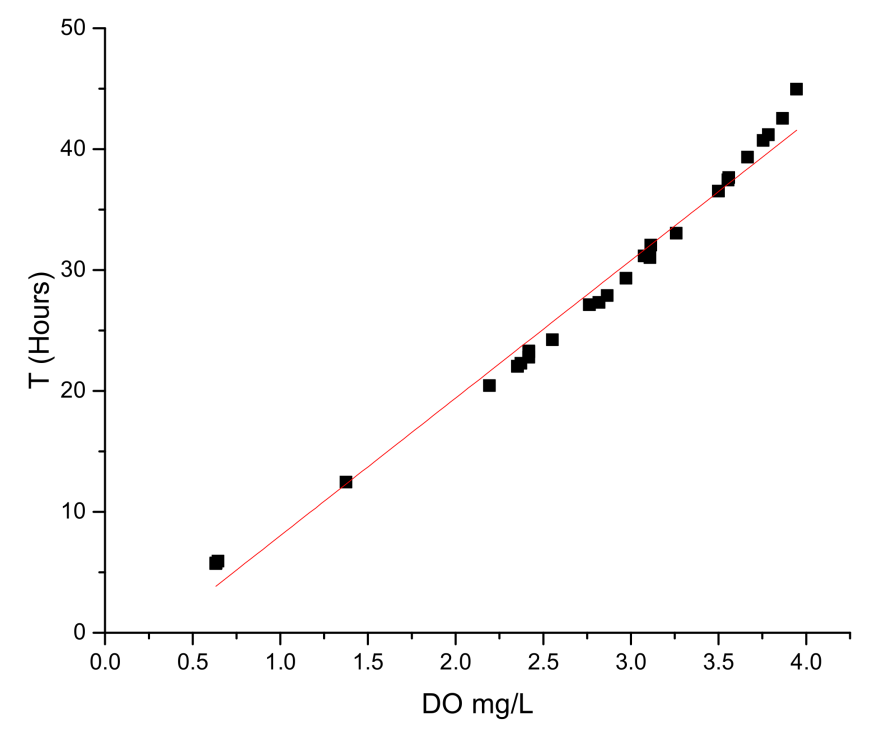

Figure 4. Linearization of respirometric kinetic.

The last parameter studied in this work was the proton production by nitrification. In Figure 5 the correlation between oxygen consumption and pumped carbonate was empirically confirmed. Levels of DO were maintained stable up to $120 \mathrm{~h}$ coincidently with catalytic activity, after that, the dissolved oxygen decreased progressively. Simultaneously, $\mathrm{Na}_{2} \mathrm{CO}_{3}$ $(1 \mathrm{M})$ was added to the bioreactor at the same time to counterbalance the $\mathrm{pH}$ changes. As it is shown in Figure 5, the relationship between DO uptake and the added volume of $\mathrm{Na}_{2} \mathrm{CO}_{3}$, results in complete oxidation of ammonium conversion, similarly to previous studies [37]. These results support the conclusion that these parameters such as DO and carbonate consumption are useful tools for monitoring the nitrification performance.

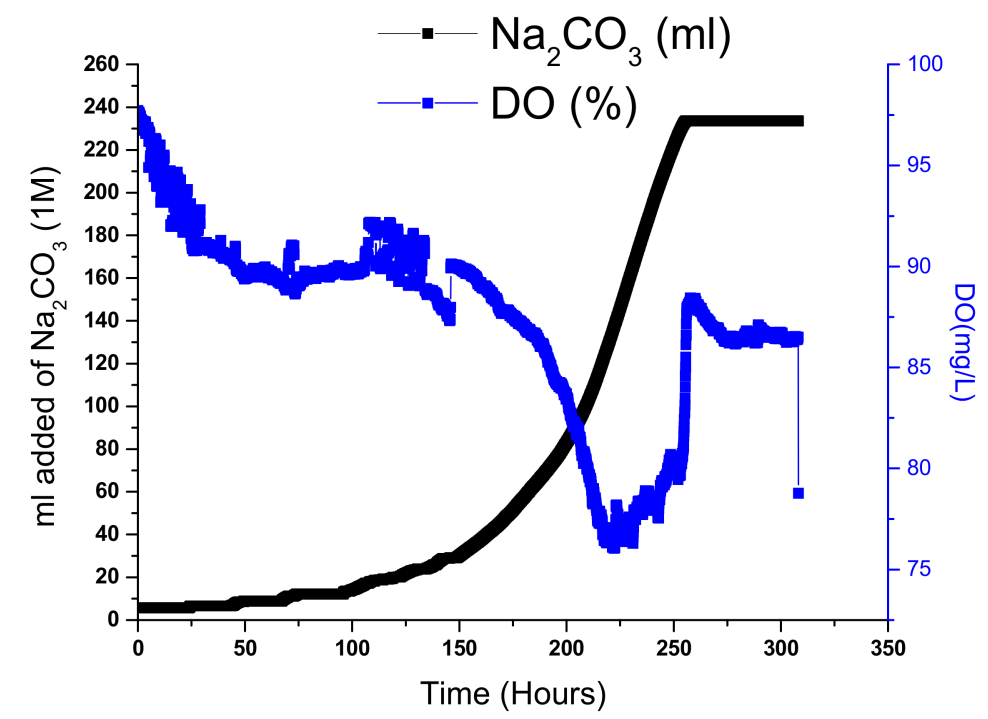

Figure 5. Relationship between DO consumption and pumped $\mathrm{Na}_{2} \mathrm{CO}_{3}{ }^{-2} 1 \mathrm{M}$.

As a result, to establish the operational range of the parameters of the nitrification process, a Monod model was used, considering $\mathrm{NH}_{4}{ }^{+}$concentration, $\mathrm{pH}$, and temperature as independent variables and $\mathrm{DO}$ and $\mathrm{HNO}_{2}$ as dependent variables. The values of the 
parameters obtained are as follows: Vmax: $251 \mathrm{mg} / \mathrm{L} \cdot$ day $\mathrm{NH}_{4}{ }^{+}$; DO 4-6 mg/L-Maximum

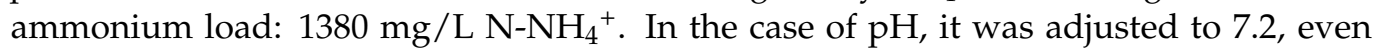
though it was demonstrated that nitrifying bacteria has an optimal metabolism at $\mathrm{pH} 7.8$ (from experimental data). In this work, it was observed that at that $\mathrm{pH}$ nitrite accumulates.

$$
\mathrm{V}=4.55 \cdot\left\{\left(251 \frac{\mathrm{mg}}{1} \cdot \text { day }\right) \cdot(7.2-\mathrm{pH}) \cdot \mathrm{e}^{\theta(\mathrm{T}-\mathrm{Tr})} \cdot\left[\frac{\mathrm{DO}(4-6 \mathrm{mg} / \mathrm{L})}{(\mathrm{Ks} \mathrm{OD}+\mathrm{DO})}\right] \cdot\left(\left[\frac{\left(\mathrm{N}-\mathrm{NH}_{4}^{+}\right)}{\left(\mathrm{N}-\mathrm{NH}_{4}^{+}\right) \cdot\left(1+\left(\frac{\mathrm{HNO} 2}{1.25}\right)\right)}\right]\right)\right\}
$$

Being, correction factor $=4.55, \mathrm{~T}=$ optimal temperature $\left({ }^{\circ} \mathrm{C}\right), \mathrm{Tr}=$ reference temperature $\left({ }^{\circ} \mathrm{C}\right), \mathrm{DO}=$ Dissolve Oxygen $(\mathrm{mg} / \mathrm{L}), \mathrm{KS}_{\mathrm{DO}}$ Affinity constant of oxygen $(\mathrm{mg} / \mathrm{L})$, $\mathrm{HNO}_{2}=$ Nitrous acid concentration $(\mathrm{mg} / \mathrm{L})$.

A common problem regarding this model is its application to real effluent conditions that differ from the standardized synthetic medium. When nitrification assay is run using BNRW, heterotrophic biomass already presents competes with autotrophic bacteria due to the high metabolic rate, affecting the nitrification performance.

\subsection{Control of ORP and Relation with Monod Parameters under Autotrophic Conditions}

Nitrification kinetics can be studied under environmental conditions with high alkalinity, COD, and DO levels, using oxide-reduction potential (ORP) as a control parameter to establish nitrification conditions. The parameters used to stimulate autotrophic biomass should maintain an oxidative environment and can be monitored by ORP values.

The biotechnological challenge is to control the efficiency by autotrophic biomass and to prevent unwanted inhibition conditions due to semi-continuous load and wastewater flow. In the bibliography, there are a scarce number of studies that use a dynamic ORP control technique to complement other parameters such as $\mathrm{pH}$ and/or DO to monitor nitrification processes. In those studies, the use of the Nernst method was suggested to obtain information related to nitrogen removal dynamics as was applied to the model proposed by Chang $[36,54]$.

To obtain the relationship between ORP with other control parameters as $\mathrm{pH}$ and a load of $\mathrm{NH}_{4}{ }^{+}$under controlled conditions, several assays were carried out using the synthetic medium. Ammonia is oxidized to $\mathrm{NO}_{2}{ }^{-}$, as a consequence of a bacterial shift, under aerobic culture based on a one-to-one stoichiometric relation for the oxidizing and the reducing species. Figure 6 shows changes in $\mathrm{ORP}, \mathrm{pH}, \mathrm{NH}_{4}{ }^{+}$, and $\mathrm{NO}_{2}{ }^{-}$during a ten days treatment assay.

At the initial stage from day 1 to day 4, ORP values increased from $0 \mathrm{mV}$ to $100 \mathrm{mV}$, when the temperature cooled down from sterilization to room temperature, and DO reach normal levels. During the second stage, from day 4 to 8 of the kinetic process, DO values slowly shift from $100 \mathrm{mV}$ to $150 \mathrm{mV}$, in a similar way as the initial stage.

The Nernst equation is based on a 1:1 ratio stoichiometric relationship of the species involved in the chemical equation and can be used to relate the measured ORP values that indicate the degree of the chemical reaction.

$$
\mathrm{ORP}=-340 \mathrm{mV}+\left(\frac{0.059}{6} \cdot \log \mathrm{DO}\right)+\left\{61 \cdot \mathrm{pH}-59.88 \cdot \log \frac{\left[\mathrm{NH}_{4}\right]}{\left[\mathrm{NO}_{2}\right]}\right\}
$$

Similar results were found from empirical data analyzed by Anthonisen [51] as regards $\mathrm{pH}$ and FA concentration; besides, the values obtained in this work were coincident with the Pourboix graph and the thermodynamics parameters [32]. 


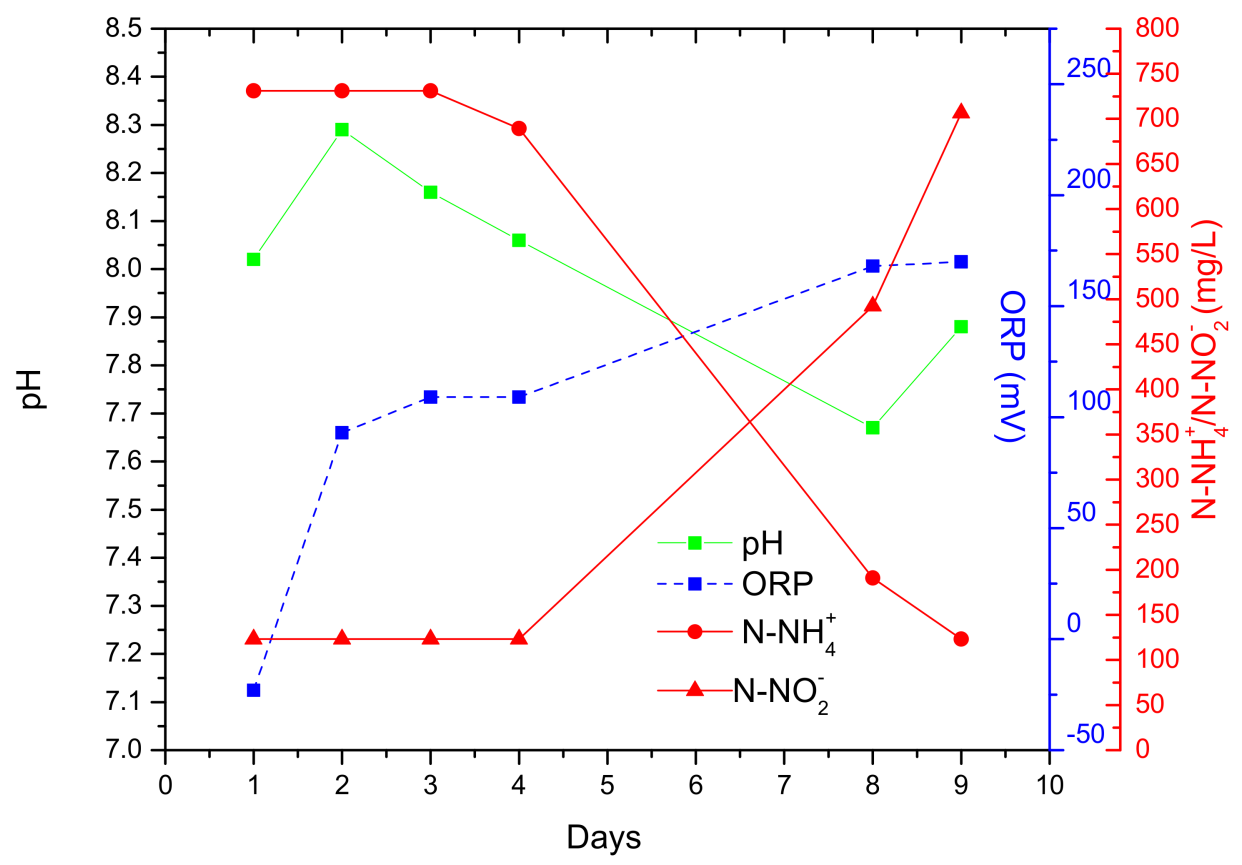

Figure 6. Evolution of nitrification process and the relation to ORP.

Linear non-equilibrium thermodynamics was implemented to simulate the biological nitrification process and compared it to ammonium oxidation. Empirical variation in the ORP was obtained in measuring changes in $\mathrm{NH}_{4}{ }^{+}, \mathrm{NO}_{3}{ }^{-}$and $\mathrm{NO}_{2}{ }^{-}$concentrations (Figure 7). While in Figure 8, it is shown the correlation between empirical and simulated ORP. The results indicate acceptable correlations on molarities of electrons transferred. The simulation model was completed based on the Nernst equations for ammonium oxidation, including a mathematical model to evaluate the influence of variables as $\mathrm{pH}, \mathrm{DO}$, and $\mathrm{NH}_{4}{ }^{+}$. The results can be interpreted as a correct qualitative description of this novel model concept.

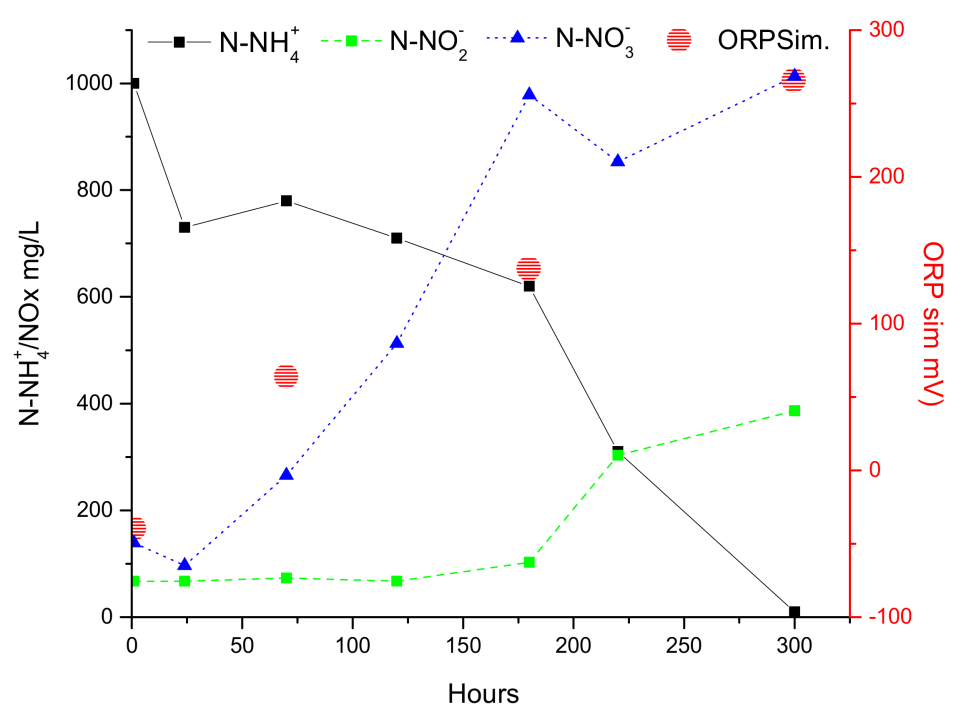

Figure 7. Simulation derivate by ORP and empirical data (red circle) and the evolution of nitrogen oxidation. 

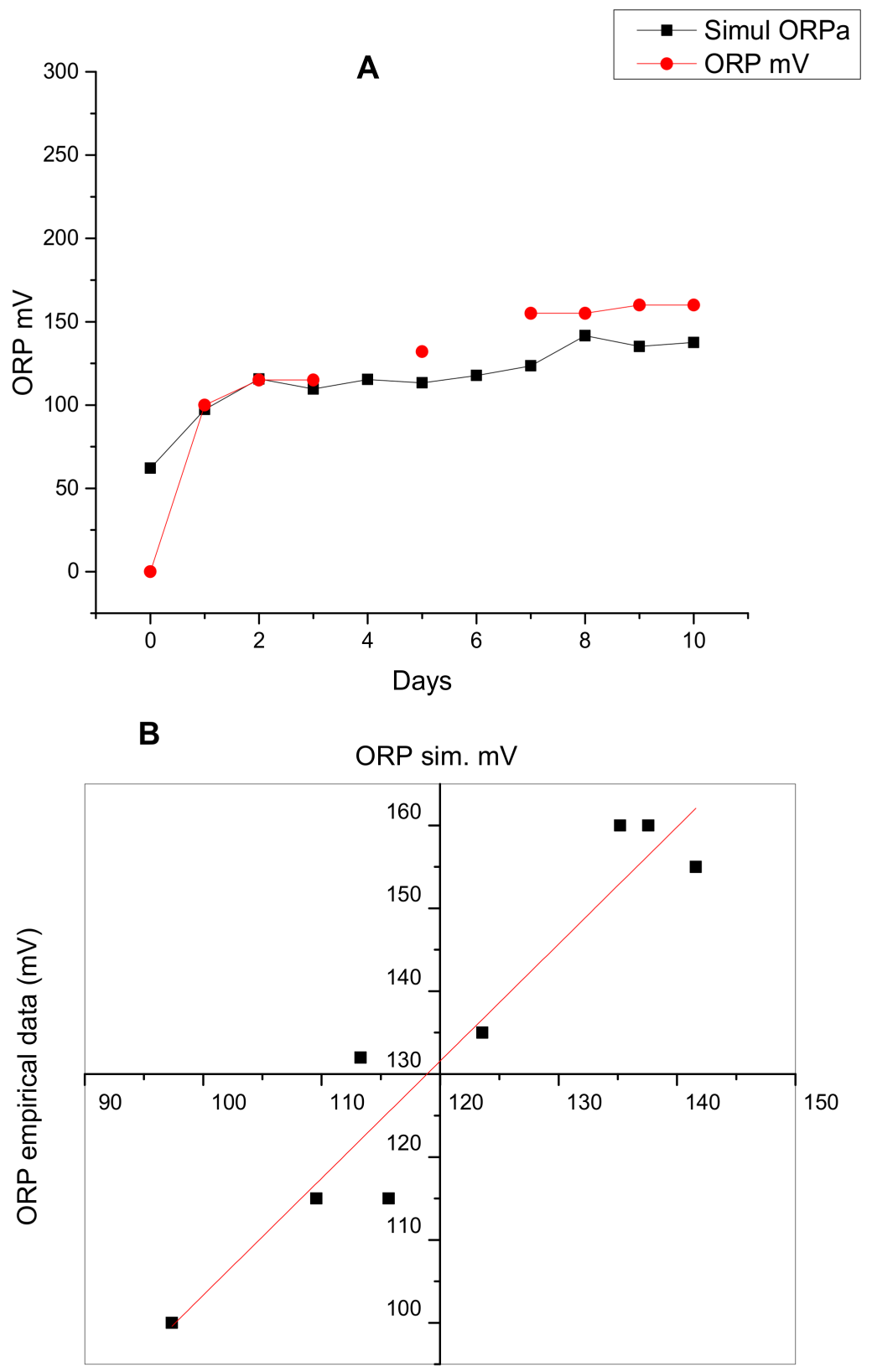

Figure 8. Simulated nitrification over ORP values. (A) values obtained by simulation and (B) Regression analysis between empirical and simulated data.

These findings are coincident with previous observations [36,50] where the redox reactions reflect the transfer of an electron between chemical species and bacteria (catalytic). The reaction is governed by thermodynamic parameters such as nitrogen species concentration, $\mathrm{DO}, \mathrm{pH}$, and ORP [37]. There is a three-way convergence among the thermodynamics of half-reactions (ORP), the physiology of microorganisms (DO), and the presence of chemical constituents in naturally electron acceptors, that dominate physiological reactions of microorganisms which provides criteria for monitoring nitrifying bacteria activities.

Hence, the results obtained using the ORP model where the intersection of ORP, DO and $\mathrm{pH}$ are represented. The best conditions for nitrifying bacteria are identified as red zones where oxidative condition prevails and the Nernst equation has the major increment in the oxidation of ammonium (Figure 9). 


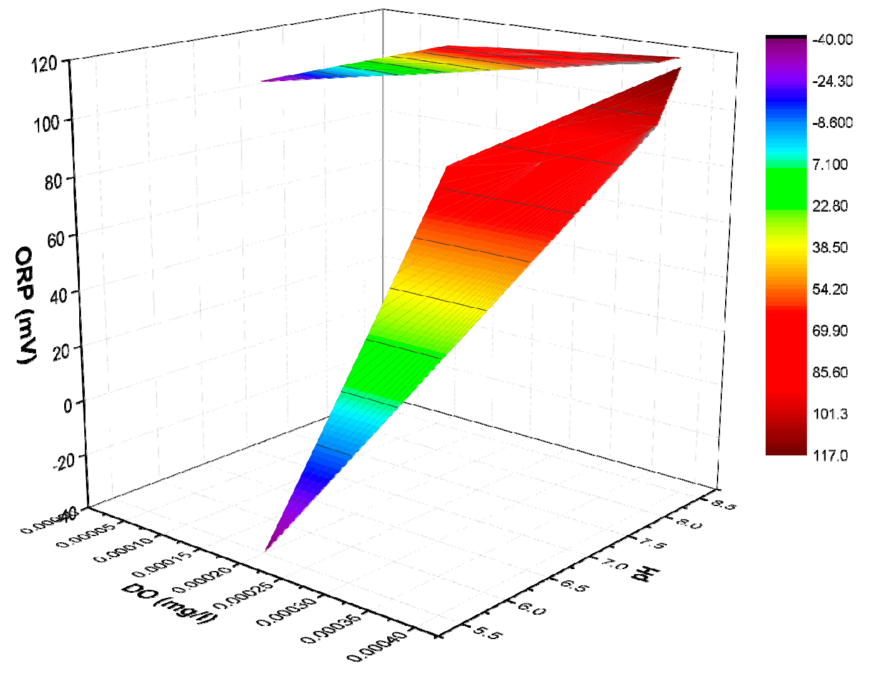

Figure 9. The intersection of ORP, DO, and $\mathrm{pH}$ indicating the best conditions for nitrifying bacteria.

\subsection{Inhibition Assays: Maximum Load of BRNW}

In general, research articles focused on operating a simulated effluent or by using simulation software $[55,56]$. In this work, the Monod model and Nernst equation were tested on diluted BRNW.

As expected, concentrations of BRNW above $20 \%$ inhibit ammonia oxidizers as it is shown in Figure 10 (green line) while nitrification activities were not affected at 5, 10, and $15 \%$ of BRNW dilutions, the ratio $50 \%$ showed total inhibition (data not shown). Probably, the inhibition has been induced by free ammonia due to its high concentration and $\mathrm{pH}$; for example, to $850 \mathrm{mg} / \mathrm{L} \mathrm{N}-\mathrm{NH}_{4}{ }^{+}$at $25^{\circ} \mathrm{C}$ and $\mathrm{pH}=7.8 \mathrm{FA}=27 \mathrm{mg} / \mathrm{L}$; however at $\mathrm{pH}=7.2$ $\mathrm{FA}=7.49 \mathrm{mg} / \mathrm{L}$. Furthermore, nuclear wastewater contains uranium $(600 \mathrm{mg} / \mathrm{L})$ and TBP which presents high toxicity and inhibits bacterial growth.

Nitrate is not observed at $15 \%$ because COD concentration could favor a simultaneous denitrification process. This observation is related to Figure $10 \mathrm{~A}$, where $\mathrm{N}-\mathrm{NH}_{4}{ }^{+}$decrease is evident at that conditions. This result could be due to denitrification bacteria already present in the wastewater (Figure 10C). Nitrite were not observed in all dilutions of BRNW, probably for the complete oxidation of ammonium by bacteria.

In previous studies, it was demonstrated that attached bacteria has a better performance compared to planktonic cultures. The major advantage of employing nitrifying attached biomass is that they can provide a relatively consistent culture. Added to that, other parameters such as $\mathrm{pH}, \mathrm{DO}$ and ORP can be adjusted to bring the best physicochemical environment for nitrifying attached bacteria.

The process was performed with low COD/N ratios in BRNW. A carbonate source was added to the media to increase the inorganic carbon to enhance autotrophic bacteria.

Uranium present in BRNW form complex with carbonate. Carbonate complexes are comparable to chelating agents as EDTA, NTA, and DTPA which alter treatment performance due to different equilibria. The concentrations of these species are governed by the acid dissociation constant $\mathrm{K}=\left[\mathrm{H}^{+}\right]$. $\left[\mathrm{HCO}_{3}^{-}\right] /\left[\mathrm{H}_{2} \mathrm{CO}_{3}\right]$.

Once the controlled parameters assessed in previous assays were adjusted to operate in a BRNW, a longer treatment period (100 days) was set in a bioreactor (see Section 2.7). Figure 11 shows the cultures in a semi-continuous process with an agitation of $120 \mathrm{rpm}$ to guarantee no limitations in the oxygen supplies. The immobilized bacteria culture showed, at the final stage of the process, an increment of the nitrification performance which is probably due to the biofilm maturity of the bacterial consortium $[57,58]$. 

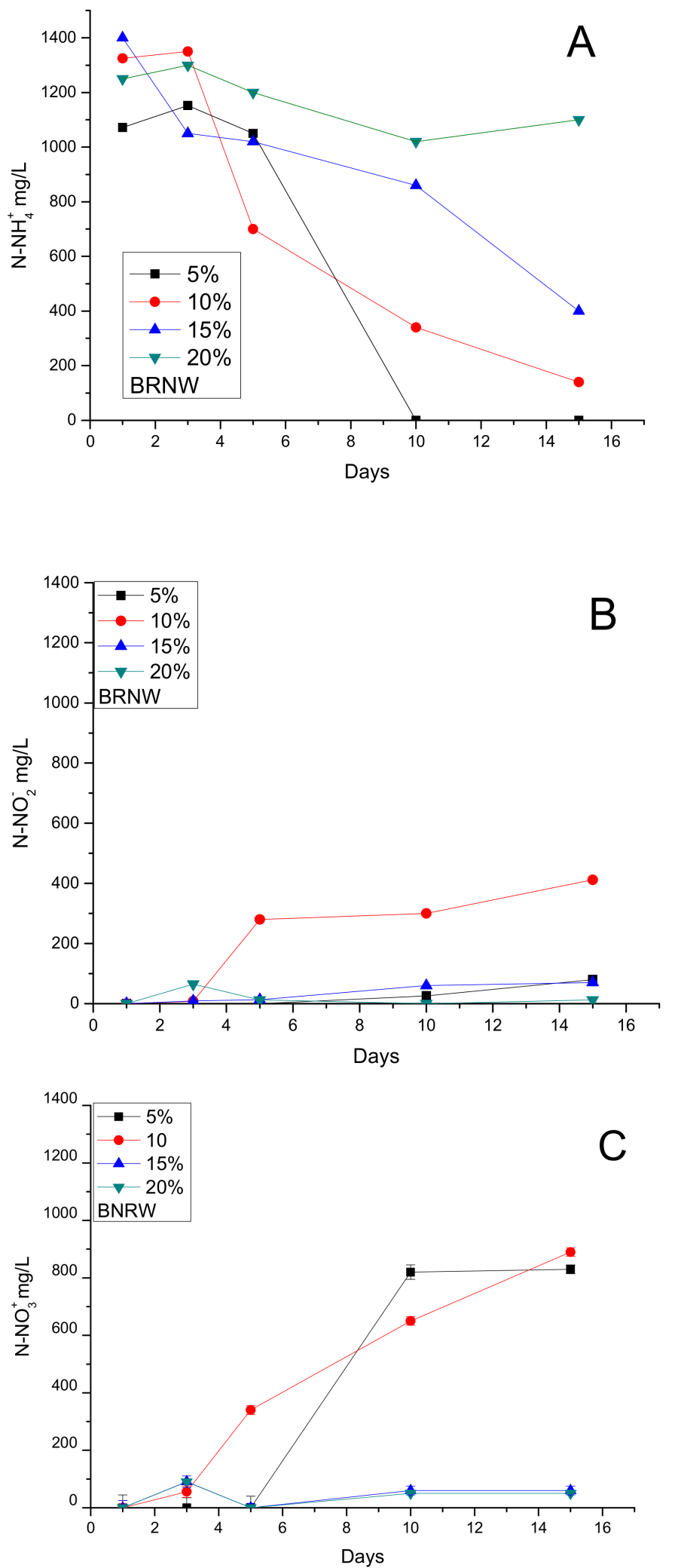

Figure 10. Inhibition of nitrification by BRNW. Performance of (A) N-NH${ }_{4}{ }^{+} \mathrm{mg} / \mathrm{L},(\mathbf{B}) \mathrm{N}^{-\mathrm{NO}_{2}}{ }^{-}$ $\mathrm{mg} / \mathrm{L}$ and $(\mathrm{C}) \mathrm{N}^{-\mathrm{NO}_{3}}{ }^{-}$at different BRNW concentrations. 

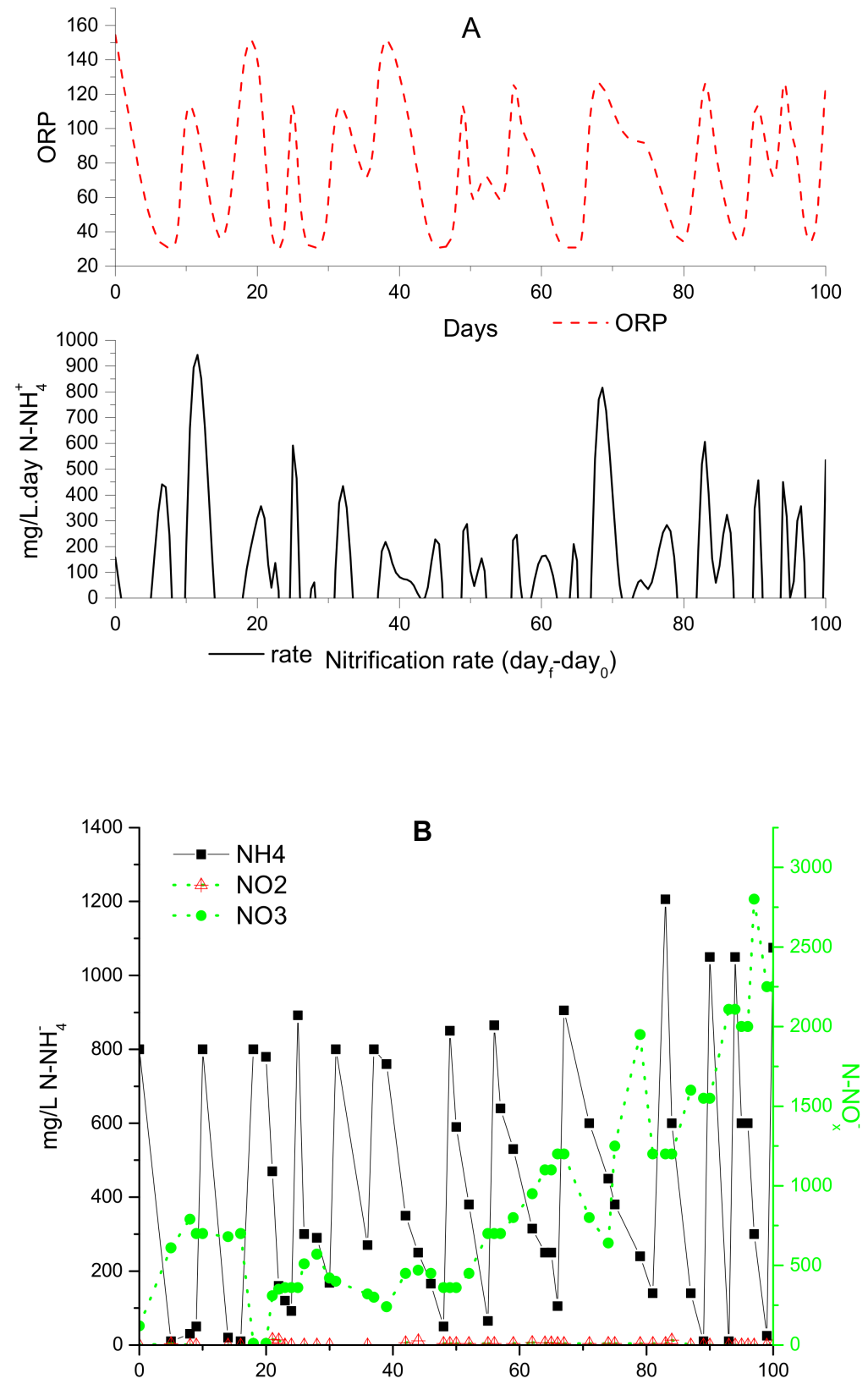

Figure 11. Nitrification in semi-continuous process at 100 days with attached biomass: (A) ORP measured (above figure) and nitrification rate (below figure) (B) Ammonium conversion in the nitrification process.

One of the most striking features is the performance of modelization applied on real wastewater in a large period of time. In scale-up operation conditions, the nitrification process was performed under ORP control within a range, based on the Monod model, to ensure an oxidant environment to enhance nitrifier bacteria, maintaining $\mathrm{DO}$ levels, $\mathrm{pH}$, and temperature.

It was observed that the model can be scaled-up for the design of a pilot nitrifying bioreactor and the operation conditions were defined as follows:

$$
\mathrm{V}=4.55 \cdot\left\{\left(251 \frac{\mathrm{mg}}{1} \text {.day }\right) \cdot(7.2-\mathrm{pH}) \cdot \mathrm{e}^{\mathrm{\theta}(\mathrm{T}-\mathrm{Tr})} \cdot\left[\frac{\mathrm{OD}}{\left(\mathrm{KsOD}_{\mathrm{OD}}+\mathrm{OD}\right)}\right] \cdot\left(\left[\frac{\left(\mathrm{N}-\mathrm{NH}_{4}^{+}\right)}{\left(\mathrm{N}-\mathrm{NH}_{4}^{+}\right) \cdot\left(1+\left(\frac{\mathrm{HNO} 2}{1.25}\right)\right)}\right]\right)\right\}_{25{ }^{\circ} \mathrm{C}}
$$


The ORP model used was according to the next expression:

$$
\mathrm{E}=-340 \mathrm{mV}+\left(\frac{0.059}{6} \cdot \mathrm{og} \mathrm{DO}\right)+\left\{61 \cdot \mathrm{pH}-59.88 \cdot \log \frac{\left[\mathrm{NH}_{4}^{+}\right]}{\left[\mathrm{NO}_{\mathrm{x}}^{-}\right]}\right\}
$$

These results demonstrate the importance of combining ORP and nitrification process in complex nuclear effluents, allowing a more tuned monitoring. In this case, competition between heterotrophs and $\mathrm{AOB}$ can be avoided by ORP and $\mathrm{pH}$ manipulation.

Roy [59] shows that Kaczorek and Ledakowicz obtained a high oxidation rate on real effluent. Their study was performed from a reactor treating wastewater containing $340 \mathrm{mg} \mathrm{N}-\mathrm{NH}_{4}{ }^{+} 1 / \mathrm{d}$ with a Vmax: $116-161 \mathrm{mg} \mathrm{N}^{-\mathrm{NH}_{4}}{ }^{+} 1 / \mathrm{d}$. However, the data reported by them shows a higher nitrification rate at low substrates and stronger inhibition at higher substrate concentrations. Several studies proved the tight relationship between ORP and biochemical pathways of nitrification, and by using the Monod model the variation of the $\mathrm{pH}, \mathrm{DO}$, and TAN could be modeled to establish an online control of the process.

\section{Conclusions}

Recent studies have suggested that there are more efficient biological alternatives to eliminate ammonia than using conventional nitrification processes. Considering that the novel processes do not require neither oxygenation nor long times to transform ammonia into nitrite or nitrate. However, such new technologies were not used for nuclear effluents where a high load of nitrogen and COD represent an unfavorable condition for microorganisms. In this work, it was found that under strict control of physicochemical parameters the activity of nitrifier bacteria could be adjusted to optimize the performance even in an effluent with a high load of nitrogen and COD.

In addition, the advantage of the present methodology consisted of using a Blended Real Nuclear Wastewater (BRNW) that helps neutralize acid $\mathrm{pH}$ present in the nuclear wastewater. The principal advantages of this procedure were not only reducing the cost of reagents and treating the whole effluent but also contributing to obtain acceptable oxidation of ammonia despite a high load of nitrogen and COD and a large period of effluent treatment.

Predicting parameters obtained by the Monod model were corroborated in an oxidation environment with ORP controlled in a high strength condition with real nuclear wastewater. The techniques and models used in this work show great potential for oxidizing ammonium from real complex nuclear wastewater with low cost and robust performance.

The next step to prove the efficiency of the methodology proposed involves a continuous operation at a pilot scale and continue with denitrification. This process represents sustainable biotechnology to recycling water from the uranium industry.

Author Contributions: Conceptualization, M.V.; methodology, M.V.; software, M.V.; validation, M.V. and P.S.P.; formal analysis, M.V., A.R. and P.S.P.; investigation, M.V., A.R. and P.S.P.; resources, M.V. and P.S.P.; data curation, M.V.; writing-original draft preparation, M.V., A.R. and P.S.P.; writingreview and editing, M.V., A.R. and P.S.P.; visualization, M.V., A.R. and P.S.P.; supervision, M.V. and P.S.P.; project administration, M.V. and P.S.P.; funding acquisition, M.V. All authors have read and agreed to the published version of the manuscript.

Funding: This research received no external funding from National Commission of Atomic Energy.

Institutional Review Board Statement: Not applicable.

Informed Consent Statement: Not applicable.

Conflicts of Interest: The authors declare no conflict of interest. 


\section{References}

1. Cao, B.; Wu, J.; Yang, T.; Ma, X.; Chen, Y. Preliminary Study on Nuclear Fuel Cycle Scenarios of China before 2050. Energy Procedia 2013, 39, 294-299. [CrossRef]

2. Setting Authorized Limits for Radioactive Discharges: Practical Issues to Consider. Available online: https://www.iaea. org/publications/8312/setting-authorized-limits-for-radioactive-discharges-practical-issues-to-consider (accessed on 27 March 2021).

3. Edwards, C.R.; Oliver, A.J. Uranium Processing: A Review of Current Methods and Technology. JOM 2000, 52, 12-20. [CrossRef]

4. Bhanot, P.; Celin, S.M.; Sreekrishnan, T.R.; Kalsi, A.; Sahai, S.K.; Sharma, P. Application of Integrated Treatment Strategies for Explosive Industry Wastewater-A Critical Review. J. Water Process Eng. 2020, 35, 101232. [CrossRef]

5. Katsoyiannis, I.A.; Zouboulis, A.I. Removal of Uranium from Contaminated Drinking Water: A Mini Review of Available Treatment Methods. Desalination Water Treat. 2013, 51, 2915-2925. [CrossRef]

6. InfoLEG-Ministerio de Economía y Finanzas Públicas-Argentina. Available online: http://servicios.infoleg.gob.ar/ infolegInternet/anexos/40000-44999/43795/norma.htm (accessed on 31 March 2021).

7. National Research Council Uranium Mining in Virginia: Scientific, Technical, Environmental, Human Health and Safety, and Regulatory Aspects of Uranium Mining and Processing in Virginia; The National Academies Press: Washington, DC, USA, 2011; ISBN 978-0-309-22087-3.

8. Smičiklas, I.; Šljivić-Ivanović, M. Radioactive Contamination of the Soil: Assessments of Pollutants Mobility with Implication to Remediation Strategies. Soil Contam.-Curr. Conseq. Furth. Solut. 2016. [CrossRef]

9. Orrego, P.; Hernández, J.; Manríquez, J. Modeling Operational Parameters for Uranium Dioxide Production Reactor through Uranium Trioxide Reaction Using Hydrogen. World J. Nucl. Sci. Technol. 2016, 06, 131-139. [CrossRef]

10. Jeong, D.; Cho, K.; Lee, C.-H.; Lee, S.; Bae, H. Integration of Forward Osmosis Process and a Continuous Airlift Nitrifying Bioreactor Containing PVA/Alginate-Immobilized Cells. Chem. Eng. J. 2016, 306, 1212-1222. [CrossRef]

11. Quan, X.; Huang, K.; Li, M.; Lan, M.; Li, B. Nitrogen Removal Performance of Municipal Reverse Osmosis Concentrate with Low C/N Ratio by Membrane-Aerated Biofilm Reactor. Front. Environ. Sci. Eng. 2018, 12, 5. [CrossRef]

12. Zero Liquid Discharge (ZLD). Available online: https://condorchem.com/en/zld/ (accessed on 6 October 2018).

13. Roch Nicholas Analysis of Ammonia Removal from Wastewater Market: Feasibility of Saltworks Introducing New Technology. Master's Thesis, Simon Fraser University, Burnaby, BC, Canada, 2015.

14. Dhangar, K.; Kumar, M. Tricks and Tracks in Removal of Emerging Contaminants from the Wastewater through Hybrid Treatment Systems: A Review. Sci. Total Environ. 2020, 738, 140320. [CrossRef]

15. Schoeman, J.; Steyn, A. Nitrate Removal with Reverse Osmosis in a Rural Area in South Africa. Desalination 2003, 155, 15-26. [CrossRef]

16. Gadd, G.M.; Pan, X. Biomineralization, Bioremediation and Biorecovery of Toxic Metals and Radionuclides. Geomicrobiol. J. 2016, 33, 175-178. [CrossRef]

17. Puyol, D.; Batstone, D.J.; Hülsen, T.; Astals, S.; Peces, M.; Krömer, J.O. Resource Recovery from Wastewater by Biological Technologies: Opportunities, Challenges, and Prospects. Front. Microbiol. 2017, 7. [CrossRef]

18. Daphne, L. Stoner Biotechnological Treatment of Liquid and Solid Inorganic Wastes; Library of Congress Cataloging-in-Publication Data; LEWIS PUBLISHERS; CRC Press: Boca Raton, FL, USA, 1993; pp. 71-95, ISBN 978-1-315-13844-2.

19. Rai, A.; Chauhan, P.S.; Bhattacharya, S. Remediation of Industrial Effluents. In Water Remediation; Energy, Environment, and Sustainability; Bhattacharya, S., Gupta, A.B., Gupta, A., Pandey, A., Eds.; Springer: Singapore, 2018; pp. 171-187, ISBN 978-981-10-7551-3.

20. Waugh, W.J.; Glenn, E.P.; Benson, C.H.; Albright, W.H.; Brusseau, M.L.; Bush, R.P.; Dayvault, J. Applications of Ecological Engineering Remedies for Uranium Processing Sites; US Department of Energy/Office of Legacy Management: Washington, DC, USA, 2016 ; p. 2.

21. Jaramillo, F.; Orchard, M.; Muñoz, C.; Zamorano, M.; Antileo, C. Advanced Strategies to Improve Nitrification Process in Sequencing Batch Reactors-A Review. J. Environ. Manag. 2018, 218, 154-164. [CrossRef]

22. What Is the Best Biological Process for Nitrogen Removal: When and Why? I Environmental Science \& Technology. Available online: https:/ / pubs.acs.org/doi/10.1021/acs.est.7b05832 (accessed on 29 December 2020).

23. Sri Shalini, S.; Joseph, K. Combined SHARON and ANAMMOX Processes for Ammoniacal Nitrogen Stabilisation in Landfill Bioreactors. Bioresour. Technol. 2018, 250, 723-732. [CrossRef]

24. Stoichiometric Evaluation of Partial Nitritation, Anammox and Denitrification Processes in a Sequencing Batch Reactor and Interpretation of Online Monitoring Parameters. Available online: https:/ / europepmc.org/article/med/27614985 (accessed on 27 March 2021).

25. Wu, P.; Zhang, X.; Wang, X.; Wang, C.; Faustin, F.; Liu, W. Characterization of the Start-up of Single and Two-Stage Anammox Processes with Real Low-Strength Wastewater Treatment. Chemosphere 2020, 245, 125572. [CrossRef]

26. Li, J.; Peng, Y.; Zhang, L.; Li, X.; Zhang, Q.; Yang, S.; Gao, Y.; Li, S. Improving Efficiency and Stability of Anammox through Sequentially Coupling Nitritation and Denitritation in a Single-Stage Bioreactor. Environ. Sci. Technol. 2020, 54, 10859-10867. [CrossRef]

27. Huynh, T.V.; Nguyen, P.D.; Phan, T.N.; Luong, D.H.; Truong, T.T.V.; Huynh, K.A.; Furukawa, K. Application of CANON Process for Nitrogen Removal from Anaerobically Pretreated Husbandry Wastewater. Int. Biodeterior. Biodegrad. 2019, 136, 15-23. [CrossRef] 
28. Lv, Y.; Chen, X.; Wang, L.; Ju, K.; Chen, X.; Miao, R.; Wang, X. Microprofiles of Activated Sludge Aggregates Using Microelectrodes in Completely Autotrophic Nitrogen Removal over Nitrite (CANON) Reactor. Front. Environ. Sci. Eng. 2016. [CrossRef]

29. Pochana, K.; Keller, J. Study of Factors Affecting Simultaneous Nitrification and Denitrification (SND). Water Sci. Technol. 1999, 39, 61-68. [CrossRef]

30. Lozano Avilés, A.B.; Del Cerro Velázquez, F.; Lloréns Pascual del Riquelme, M. Methodology for Energy Optimization in Wastewater Treatment Plants. Phase III: Implementation of an Integral Control System for the Aeration Stage in the Biological Process of Activated Sludge and the Membrane Biological Reactor. Sensors 2020, 20, 4342. [CrossRef]

31. Majtacz, J.; Grubba, D.; Czerwionka, K. Application of the Anammox Process for Treatment of Liquid Phase Digestate. Water 2020, 12, 2965. [CrossRef]

32. Gao, D.-W.; Peng, Y.-Z.; Liang, H.; Wang, P. Using Oxidation-Reduction Potential (ORP) and PH Value for Process Control of Shortcut Nitrification-Denitrification. J. Environ. Sci. Health A Toxic Hazard. Subst. Environ. Eng. 2003, 38, 2933-2942. [CrossRef]

33. Rodriguez-Sanchez, A.; Margareto, A.; Robledo-Mahon, T.; Aranda, E.; Diaz-Cruz, S.; Gonzalez-Lopez, J.; Barcelo, D.; Vahala, R.; Gonzalez-Martinez, A. Performance and Bacterial Community Structure of a Granular Autotrophic Nitrogen Removal Bioreactor Amended with High Antibiotic Concentrations. Chem. Eng. J. 2017, 325, 257-269. [CrossRef]

34. Yu, R.-F.; Liaw, S.-L.; Chang, C.-N.; Lu, H.-J.; Cheng, W.-Y. Monitoring and Control Using On-Line Orp on the Continuous-Flow Activated Sludge Batch Reactor System. Water Sci. Technol. 1997, 35, 57-66. [CrossRef]

35. Rodríguez, D.C.; Pino, N.; Peñuela, G. Monitoring the Removal of Nitrogen by Applying a Nitrification-Denitrification Process in a Sequencing Batch Reactor (SBR). Bioresour. Technol. 2011, 102, 2316-2321. [CrossRef] [PubMed]

36. Chang, C.-N.; Cheng, H.-B.; Chao, A.C. Applying the Nernst Equation to Simulate Redox Potential Variations for Biological Nitrification and Denitrification Processes. Environ. Sci. Technol. 2004, 38, 1807-1812. [CrossRef] [PubMed]

37. Ying, X.-B.; Tang, C.-Y.; Guo, W.; Sheng, D.-S.; Wang, M.-Z.; Feng, H.-J. Quantifying the Electron-Donating and -Accepting Capacities of Wastewater for Evaluating and Optimizing Biological Wastewater Treatment Processes. J. Environ. Sci. 2021, 102, 235-243. [CrossRef]

38. Kassem Alef, P.N. Methods in Applied Soil Microbiology and Biochemistry, 1st ed.; 1era 1995; Academic Press: London, UK, 2002; ISBN 978-0-08-052748-2.

39. Ying, Q.; Xiao-tong, C.; Bing, L.; Gen-na, F.; Yang, W.; You-lin, S.; Zhen-ming, L.; Ya-ping, T.; Chun-he, T. The Conceptual Flowsheet of Effluent Treatment during Preparing Spherical Fuel Elements of HTR. Nucl. Eng. Des. 2014, 271, 189-192. [CrossRef]

40. How Uranium Ore Is Made into Nuclear Fuel—World Nuclear Association. Available online: https:/ / www.world-nuclear.org/ nuclear-basics/how-is-uranium-ore-made-into-nuclear-fuel.aspx (accessed on 27 July 2019).

41. Chen, X.; He, L.; Liu, B.; Tang, Y.; Tang, C. The Uranium Recovery from UO2 Kernel Production Effluent. Nucl. Eng. Des. 2016, 310, 187-191. [CrossRef]

42. Métodos Normalizados Para el Análisis de Aguas Potables y Residuales APHA-AWWA-WPCF 978-84-7978-031-9. Available online: http: / / www.diazdesantosargentina.com/ / libros/apha-awwa-wpcf-metodos-normalizados-para-el-analisis-de-aguaspotables-y-residuales-L03000310201.html (accessed on 30 May 2021).

43. Bhattacharya, R.; Mazumder, D. Evaluation of Nitrification Kinetics for Treating Ammonium Nitrogen Enriched Wastewater in Moving Bed Hybrid Bioreactor. J. Environ. Chem. Eng. 2020, 104589. [CrossRef]

44. Monod, J.; Wyman, J.; Changeux, J.-P. On the Nature of Allosteric Transitions: A Plausible Model. J. Mol. Biol. 1965, 12, 88-118. [CrossRef]

45. Carrera, J.; Jubany, I.; Carvallo, L.; Chamy, R.; Lafuente, J. Kinetic Models for Nitrification Inhibition by Ammonium and Nitrite in a Suspended and an Immobilised Biomass Systems. Process Biochem. 2004, 39, 1159-1165. [CrossRef]

46. Wiesmann, U. Biological Nitrogen Removal from Wastewater. Adv. Biochem. Eng. Biotechnol. 1994, 51, 113-154. [CrossRef] [PubMed]

47. Ciudad, G.; Werner, A.; Bornhardt, C.; Muñoz, C.; Antileo, C. Differential Kinetics of Ammonia- and Nitrite-Oxidizing Bacteria: A Simple Kinetic Study Based on Oxygen Affinity and Proton Release during Nitrification. Process Biochem. 2006, 41, 1764-1772. [CrossRef]

48. Ciudad, G.; González, R.; Bornhardt, C.; Antileo, C. Modes of Operation and PH Control as Enhancement Factors for Partial Nitrification with Oxygen Transport Limitation. Water Res. 2007, 41, 4621-4629. [CrossRef] [PubMed]

49. Venturini, M.; Perez, M.; Curutchet, G.; Silva Paulo, P.; Pizarro, R. Biological Nitrogen Removal of Wastewater from the Nuclear Industry with High Load. In Environmental Biotechnology and Engineering Advances; 2016; CINVESTAV: Mexico City, Mexico, 2018; pp. 716-726, ISBN 978-607-9023-51-5.

50. Liu, Y.; Ngo, H.H.; Guo, W.; Peng, L.; Wang, D.; Ni, B. The Roles of Free Ammonia (FA) in Biological Wastewater Treatment Processes: A Review. Environ. Int. 2019, 123, 10-19. [CrossRef] [PubMed]

51. Anthonisen, A.C.; Loehr, R.C.; Prakasam, T.B.S.; Srinath, E.G. Inhibition of Nitrification by Ammonia and Nitrous Acid. Journal (Water Pollut. Control Fed.) 1976, 48, 835-852. [PubMed]

52. Chandran, K.; Hu, Z.; Smets, B.F. A Critical Comparison of Extant Batch Respirometric and Substrate Depletion Assays for Estimation of Nitrification Biokinetics. Biotechnol. Bioeng. 2008, 101, 62-72. [CrossRef]

53. Ginestet, P.; Audic, J.M.; Urbain, V.; Block, J.C. Estimation of Nitrifying Bacterial Activities by Measuring Oxygen Uptake in the Presence of the Metabolic Inhibitors Allylthiourea and Azide. Appl. Environ. Microbiol. 1998, 64, 2266-2268. [CrossRef] 
54. Cheng, H.-B.; Kumar, M.; Lin, J.-G. Interpretation of Redox Potential Variation during Biological Denitrification Using Linear Non-Equilibrium Thermodynamic Model. Int. Biodeterior. Biodegrad. 2012, 67, 28-39. [CrossRef]

55. Muloiwa, M.; Nyende-Byakika, S.; Dinka, M. Comparison of Unstructured Kinetic Bacterial Growth Models. S. Afr. J. Chem. Eng. 2020, 33, 141-150. [CrossRef]

56. Ianus GmbH Simulation of (De-)Nitrification Tanks. Ianus-Simulation GmbH. Available online: https://ianus-simulation.de/en/ de-nitrification-tanks / (accessed on 27 May 2021).

57. dos Santos, A.L.S.; Galdino, A.C.M.; de Mello, T.P.; Ramos, L.d.S.; Branquinha, M.H.; Bolognese, A.M.; Columbano Neto, J.; Roudbary, M.; dos Santos, A.L.S.; Galdino, A.C.M.; et al. What Are the Advantages of Living in a Community? A Microbial Biofilm Perspective! Memórias do Instituto Oswaldo Cruz 2018, 113. [CrossRef]

58. Wang, X.; Wang, W.; Li, Y.; Zhang, J.; Zhang, Y.; Li, J. Biofilm Activity, Ammonia Removal and Cell Growth of the Heterotrophic Nitrifier, Acinetobacter sp., Facilitated by Exogenous N-Acyl-Homoserine Lactones. RSC Adv. 2018, 8, 30783-30793. [CrossRef]

59. Roy, D.; Benkaraache, S.; Lemay, J.-F.; Landry, D.; Drogui, P.; Tyagi, R.D. High-Strength Ammonium Wastewater Treatment by MBR: Steady-State Nitrification Kinetic Parameters. J. Water Process Eng. 2019, 32, 100945. [CrossRef] 